http://dx.doi.org/10.12775/szhf.2018.034

\title{
Leibniz jako prekursor zdrowia publicznego
}

Człowiek od zawsze troszczył się o swoje zdrowie - gdy pojawiała się choroba, usiłował ją zwalczyć, a przynajmniej opóźnić jej postępy. Jest to oczywiście determinowane przez właściwy człowiekowi instynkt samozachowawczy, jednak szczególne znaczenie ma rozwój wiedzy zwiększający nie tylko skuteczność walki z chorobami, ale także rozumienie ich przyczyn. W tym drugim aspekcie rozwój wiedzy medycznej zmienił nastawienie człowieka wobec swego stanu zdrowia, mianowicie choroba przestała być postrzegana jako dopust Boży czy przypadek losowy, a zaczęto coraz lepiej rozumieć, że możemy mieć rzeczywisty wpływ na stan własnego organizmu i poprzez określone działania zmniejszać bądź zwiększać ryzyko zachorowań. Już w XVII wieku, w związku z przełomem, jaki dokonał się w naukach przyrodniczych, coraz bardziej stawało się oczywiste, że sposób życia człowieka, a więc higiena osobista, warunki sanitarne, jakość odżywiania itp., mają istotny wpływ na poziom zdrowotności zarówno jednostki, jak i całej populacji. Szybciej jednak dokonywał się rozwój wiedzy medycznej niż wzrost świadomości społecznej, a także zbyt niski był poziom materialny życia, aby możliwe było praktyczne 
wdrażanie w skali społecznej zaleceń prozdrowotnych formułowanych przez medyków ${ }^{1}$.

Warunkiem koniecznym utrwalenia się społecznego przekonania o potrzebie działań prozdrowotnych było nadanie im charakteru powinności quasi-moralnych, ponieważ tylko wówczas dobre zdrowie mogło zostać uznane za wartość samą w sobie, a człowiek poczuwał się do obowiązku dbania o nie systematycznie, nie zaś tylko w stanach jego pogorszenia. W XVII wieku w rozważaniach moralnych zaczęto, w powiązaniu ze wskazaniem na rozwój medycyny i nadzieje, jakie on rodził, ujmować troskę o zdrowie nie tylko jako postawę praktycznie użyteczną, ale także jako nakaz moralny. Dobrym przykładem jest Jan Amos Komeński (1592-1670), który w swych rozważaniach na temat właściwego przebiegu procesu wychowawczego dużo uwagi poświęcał zagadnieniom zdrowia. Komeński argumentował, że długość życia jednostki ma znaczenie ze względu na proces jej rozwoju, ponieważ kształcenie umysłu i zdobywanie wiedzy wymagają czasu. Komeński uznał, że Bóg daje człowiekowi długość życia właściwą dla niego, tzn. wystarczającą, aby rozwinął on samego siebie do tego poziomu, który Stwórca dla niego zaplanował, oraz zrealizował to wszystko, co mu przeznaczył do wykonania. Jeżeli zatem człowiek nie prowadzi właściwego trybu życia, czyli z lenistwa lub lekkomyślności nie wypełnia właściwą treścią każdego dnia swego życia, bądź też niewłaściwym trybem życia rujnuje swoje zdrowie i skraca swój pobyt na ziemi, to tym samym sprzeciwia się zamiarom Boga względem siebie. Zaniedbywanie własnego zdrowia, a tym bardziej świadome szkodzenie mu, staje się więc grzechem, troska o własne zdrowie staje się zaś nakazem moralnym².

Jeżeli troska o własne zdrowie jest powinnością moralną człowieka, to nie tylko on sam, ale także wszelkie instytucje społeczne oraz władze państwa mają obowiązek stwarzać odpowiednie warunki dla realizacji tej powinności. W ten sposób od XVII wieku poczynając zaczyna się rozwijać zdrowie publiczne, tj. dziedzina wiedzy medycznej zajmująca się opieką zdrowotną $\mathrm{w}$ wymiarze społecznym. Wyraźne zdynamizowanie rozwoju zdrowia publicznego nastąpiło pod koniec XIX wieku, wraz z rozwojem medycyny i wzrostem zamożności społeczeństw zachodnich. Jak wielkie znaczenie miał wzrost świadomości prozdrowotnej i rozwój zdrowia publicznego, świad-

\footnotetext{
${ }^{1}$ Maria Nowacka, „Rozwój medycyny a poziom świadomości zdrowotnej w XVII wieku”, Roczniki Filozoficzne LXII, 4 (2014).

${ }^{2}$ Maria Nowacka, „Jan Amos Komeński o powinnościach prozdrowotnych”, Idea. Studia nad strukturą i rozwojem pojęć filozoficznych XXVII (2015).
} 
czy fakt, że znaczący wzrost średniej życia w XX wieku tylko w niewielkim stopniu został spowodowany działaniami ściśle medycznymi, głównie zaś był rezultatem prewencji medycznej, lepszych warunków sanitarnych, przestrzeganiem zasad higieny, lepszą jakością pożywienia itp. To zaś musiało z kolei rodzić tendencję, aby w zakres zdrowia publicznego włączać coraz więcej działań uznanych za wskazane z prozdrowotnego punktu widzenia. Obecnie zdrowie publiczne jest nie tylko bardzo rozbudowaną dziedziną wiedzy medycznej, lecz także wywiera istotny wpływ na organizację i działanie społeczeństw w krajach rozwiniętych. Wedle definicji sformułowanej przez Światową Organizację Zdrowia (WHO) zdrowie publiczne to

zorganizowany wysiłek społeczeństwa, realizowany przede wszystkim poprzez jego instytucje publiczne, mający na celu polepszanie, promocję, ochronę i przywracanie zdrowia populacji poprzez działania zbiorowe. Wysiłek ten obejmuje między innymi takie rodzaje działań, jak analiza sytuacji zdrowotnej, nadzór zdrowotny, promocja zdrowia, zapobieganie, opanowywanie chorób zakaźnych, ochrona środowiska i dbanie o warunki sanitarne, zabezpieczanie się na wypadek klęsk żywiołowych i zagrożeń zdrowotnych, rozwój medycyny pracy $^{3}$.

Tak szeroko zakrojone cele i zadania zdrowia publicznego muszą być realizowane zbiorowym wysiłkiem danej społeczności i otrzymywać wsparcie prawno-organizacyjne ze strony państwa. Inaczej mówiąc, współcześnie uznaje się, że troska o zdrowie nie może być pozostawiona samej jednostce, lecz musi być zarówno wspierana przez państwo, jak i przez państwo w jakimś zakresie egzekwowana. Chodzi więc nie tylko o rozwój świadomości prozdrowotnej, ale także o taką organizację życia społecznego, która sprzyja nakazywanemu przez tę świadomość właściwemu postępowaniu, skłania do niego, a nawet przymusza. Zdrowie publiczne przybrało więc także charakter ideologii prozdrowotnej wdrażanej w życie środkami społecznymi i państwowymi. Za początek ideologii prozdrowotnej można uznać stanowisko Jana Amosa Komeńskiego, jednak w XVII wieku powstaje także pierwszy projekt

\footnotetext{
${ }^{3}$ „An organized effort by society, primarily through its public institutions, to improve, promote, protect and restore the health of the population through collective action. It includes services such as health situation analysis, health surveillance, health promotion, prevention, infectious disease control, environmental protection and sanitation, disaster and health emergency preparedness and response, and occupational health, among others"; WHO, dostęp: 12.01.2016, http://www.who.int/healthsystems/hss_glossary/en/index8.html.
} 
organizacji życia społecznego na gruncie tej ideologii. Prekursorem zdrowia publicznego jako zorganizowanych w wymiarze społecznym i państwowym działań prozdrowotnych był Gottfried Wilhelm Leibniz. To on jest autorem pierwszych projektów organizacji działań medycznych w skali społecznej.

Leibniz nie był lekarzem, jednak zagadnieniami medycyny interesował się żywo od początków swych badań naukowych ${ }^{4}$. Wprawdzie kwestie medyczne ciekawiły go przede wszystkim w kontekście przyrodoznawstwa, rodzącego nadzieję na szybsze postępy i większą skuteczność medycyny, ale zarazem był przekonany, że równie istotny jest sposób kształcenia lekarzy oraz prowadzenie przez nich działalności medycznej nie tylko w odniesieniu do jednostki, lecz także w odniesieniu do całych społeczności ${ }^{5}$. Większość tego, co Leibniz na temat społecznego wymiaru medycyny napisał, pozostawił nieopublikowaną. W przekładzie na język polski dostępne są cztery teksty, stanowiące dobrą wykładnię stanowiska filozofa w kwestii zdrowia publicznego: (1) Zalecenia dotyczace medycyny z przełomu 1671 i $1672 \mathrm{roku}^{6}$, (2) Propozycja utworzenia urzędu zdrowia z 1680 roku7, (3) O sposobie udoskonalenia medycyny

${ }^{4}$ Katarzyna Pękacka-Falkowska, „Młody Leibniz i medycyna jego epoki. W stronę instytucjonalizacji sztuki leczenia”, w: Filozofia medycyny - rozważania o tradycji i współczesności, red. Marcin Moskalewicz, Jan Zamojski (Poznań: Wydawnictwo Naukowe Uniwersytetu Medycznego w Poznaniu, 2017), 49-62.

${ }^{5}$ Achim Trunk, „An early concept of G. W. Leibniz regarding medicine”, w: The global and the local: The history of science and the cultural integration of Europe, Proceedings of the $2^{\text {nd }}$ ICESHS (Cracow, Poland, September 6-9, 2006),red. Michał Kokowski, dostęp: 12.05.2016,www.2iceshs.cyfronet.pl/2ICESHS_Proceedings/Chapter_13/R-5_Trunk.pdf, 374-375. Zob. także Justin E. H. Smith, „Leibniz and the life sciences”, w: The continuum companion to Leibniz, red. Brandon C. Look, (London - New York: Continuum International Publishing Group, 2011), 262. Por. Jacques Chazaud, „G. W. Leibniz: Médecine et sciences de la vie”, Histoire des Sciences Médicales XXIX, 3 (1995). Pisma Leibniza poruszające zagadnienia medyczne pozostały w rękopisach. Aktualnie realizowany jest projekt ich wydania: The Leibniz Edition Project, Series VIII. Zeskanowane oryginały znaleźć można na stronie: http://leibnizviii.bbaw. de/Leibniz_Reihe_8/.

${ }^{6}$ Gottfried Wilhelm Leibniz, „Zalecenia dotyczące medycyny”, tłum. K. Pękacka-Falkowska, Klio. Czasopismo poświęcone dziejom Polski i powszechnym 24, 1 (2013).

${ }^{7}$ Gottfried Wilhelm Leibniz, „Propozycja utworzenia urzędu zdrowia”, tłum. K. PękackaFalkowska, Klio. Czasopismo poświęcone dziejom Polski i powszechnym 15 (2010). 
z 1694 roku $^{8}$, (4) Podsumowanie dotyczące obserwacji medycznych, które należy nieustannie podejmować i kontynuować napisane zimą 1701 roku9. Pierwszy z tych tekstów, napisany w większej części po niemiecku, w mniejszej po łacinie, stanowi najpełniejszą propozycję instytucjonalnej reformy medycyny ${ }^{10}$. Drugi tekst, napisany w języku niemieckim, jest propozycją organizacyjną złożoną Domowi Hanowerskiemu, któremu Leibniz służył, trzeci stanowi fragment napisanego w języku francuskim i opublikowanego w czasopiśmie "Journal des Savants" listu do Germaina Brice'a (1652-1727), francuskiego historyka i erudyty, czwarty natomiast to napisane po niemiecku wytyczne dla nowo powstałego Pruskiego Królewskiego Towarzystwa Naukowego, którego Leibniz był inicjatorem ${ }^{11}$. Łącznie pozwalają one ujrzeć Leibniza jako wizjonera, którego propozycje dotyczące organizacji służby zdrowia zaczęły być najpełniej realizowane dopiero w naszych czasach.

Istotę wysuwanych przez Leibniza propozycji społecznego modelu służby zdrowia stanowi ścisłe powiązanie określonych rozwiązań organizacyjnych w skali całego państwa $\mathrm{z}$ działaniami mającymi wykształcić trwałe nawyki prozdrowotne u każdej jednostki. Leibniz niewątpliwie zdawał sobie sprawę, że proponowany przezeń mechanizm publicznej opieki zdrowotnej będzie funkcjonował właściwie pod warunkiem współdziałania ze strony jednostek, a to współdziałanie będzie tym lepsze, im bardziej jednostki będą przeświadczone o jego potrzebie. Podstawą propozycji Leibniza jest jednak przekonanie, że dbałość o zdrowie ludności jest obowiązkiem władzy państwowej: „Poza cnotą ducha (Gemüth) swych poddanych władza musi dbać także o zdrowie ich ciała"12. Jest zaś oczywiste, że państwo może to czynić jedynie poprzez specjalnie do tego celu powołane instytucje - dlatego Leibniz postulował powołanie urzędu zdrowia, aby „pod wyższym nadzorem sprawowanym przez przedstawicieli władzy" ${ }^{13}$ realizować określone działania

${ }^{8}$ Gottfried Wilhelm Leibniz, „O sposobie udoskonalenia medycyny”, tłum. T. Falkowski, Klio. Czasopismo poświęcone dziejom Polski i powszechnym 15 (2010).

${ }^{9}$ Gottfried Wilhelm Leibniz, „Podsumowanie dotyczące obserwacji medycznych, które należy nieustannie podejmować i kontynuować", tłum. K. Pękacka-Falkowska, Klio. Czasopismo poświęcone dziejom Polski i powszechnym 15 (2010).

${ }^{10}$ Katarzyna Pękacka-Falkowska, „Gottfried Wilhelm Leibniz o sposobie udoskonalenia medycyny”, Klio.Czasopismo poświęcone dziejom Polski i powszechnym 24, 1 (2013).

${ }^{11}$ Katarzyna Pękacka-Falkowska, „Leibniz i instytucjonalizacja opieki medycznej albo o trzech tekstach z 1690, 1694 i 1701 roku”, Klio. Czasopismo poświęcone dziejom Polski i powszechnym 15 (2010).

${ }^{12}$ Leibniz, Propozycja utworzenia urzędu zdrowia, 133.

${ }^{13}$ Ibidem, 135. 
prozdrowotne, kontrolować ich wykonywanie oraz gromadzić i wykorzystywać doświadczenie zdobywane w tym zakresie. Zalecając powołanie urzędu zdrowia, Leibniz wzoruje się na istniejących wcześniej w wielu miastach europejskich radach zdrowia (Collegia Sanitatis), które były czymś w rodzaju dzisiejszych związków zawodowych lekarzy i izb lekarskich zarazem. Filozof chce natomiast, aby zaczęły one odgrywać zasadniczo inną rolę.

[W]skazane by było, żeby najwyższa władza powołała odrębne Collegium Sanitatis i za przykładem duchowego konsystorza, jaki mają protestanci, obsadziła je po części przedstawicielami władzy (spośród których tajny radca byłby prezydentem), po części zaś medykami, spośród których najwyższy Leib-Medicus albo Comes Archiatrorum miałby kierować dyrektorium, tak jak ma to w zwyczaju czynić spowiednik w konsystorzu duchownym albo najwyższy kaznodzieja dworski w dyrektorium kościelnym ${ }^{14}$.

Leibniz proponuje więc powołanie urzędu, który byłby państwową instytucją, scentralizowaną i zhierarchizowaną, zarządzającą całością spraw związanych zarówno z opieką zdrowotną, jak i z promocją zdrowia. „Każdy urząd powinien utrzymywać uczciwego medyka, chirurga, aptekarza i wielu innych ludzi tego typu"15.

Leibniz zdaje się równą wagę przywiązywać do kontroli przez tę instytucję praktycznej działalności leczniczej, jak i do gromadzenia przez nią wszelkich informacji, których wykorzystanie mogłoby mieć wpływ na zwiększenie poziomu zdrowotności ludności kraju. To dlatego postuluje, aby lekarz mógł bez przeszkód zasięgać wszelkich informacji i prowadzić użyteczne obserwacje: „Medyk ma [mieć] przystęp generalny (łac. adito generale) do wszystkich ludzi - szczególnie wtedy, gdy jest on bezinteresowny" ${ }^{16}$. Zresztą nie tylko lekarz ma obowiązek zbierania informacji, ale wszyscy powinni poczuwać się do obowiązku przekazywania danych, które mogą okazać się użyteczne w praktyce medycznej.

Trzeba wszędzie gromadzić ludzi i im ogłaszać, że każdy, kto zna pożyteczne długo- lub krótkoterminowe kuracje, ma o nich opowiedzieć, wskazując jednocześnie na czynniki, od których są one uzależnione; i że należą mu się za to

\footnotetext{
${ }^{14}$ Ibidem. Na określenie najwyższego medyka Leibniz posłużył się nazwami stosowanymi do lekarzy osobistych cesarzy niemieckich i rzymskich.

${ }^{15}$ Leibniz, Zalecenia dotyczace medycyny, 147.

${ }^{16}$ Ibidem, 160.
} 
szacunek i liczne pochwały. Lekarza urzędowego ze względu na to, że zgromadzi tak wiele przystojnych rzeczy, także należy obdarzyć estymą ${ }^{17}$.

Leibniz jest przekonany, że każda informacja o stosowanych metodach leczenia powinna być sprawdzana przez lekarzy co do swej zasadności. Aby zaś informacje takie do medyków docierały, konieczne jest stworzenie powszechnego przekonania, że każdy człowiek ma moralny obowiązek ich przekazywania. Można to interpretować jako w istocie początek budowania społecznych postaw prozdrowotnych.

Zakres działalności postulowanego urzędu Leibniz zakreśla bardzo szeroko: z jednej strony miałby on koordynować bieżącą pracę lekarzy, z drugiej zaś być rodzajem centralnego urzędu statystycznego gromadzącego wszelkie dane pomocne w leczeniu chorób i w profilaktyce zdrowotnej. Szczególne znaczenie mają - wedle Leibniza - dane o zachorowalności na poszczególne choroby, poziomie śmiertelności, klimacie i jakości pożywienia na danym terenie. Chodzi o wykrycie wzajemnego związku między poszczególnymi czynnikami i wyciągnięcie z tego praktycznych wniosków. Oczywiście gromadzenie tego rodzaju informacji powinno być stałe i systematyczne; we wspomnianym liście do G. Brice’a zaleca Leibniz „sporządzanie roczników medycznych"18. Jest to tym bardziej ważne, ponieważ ludzie nie przywiązują należytej wagi do dbałości o zdrowie: „dusza i ciało stanowią pierwsze rzeczy, o jakich powinno się myśleć, a ostatnie, o jakich się myśli”'19. Ponieważ troska o zdrowie nie może ograniczać się do bezpośredniej dbałości o własne ciało, lecz musi być rozszerzona na całą społeczność, w której jednostka żyje, dlatego tak ważne jest gromadzenie wszelkich informacji, które mogą pomóc w poznawaniu przyczyn schorzeń i znajdywaniu środków zaradczych, w szczególności zaś porównywanie rozmaitych czynników znaczących dla stanu zdrowotności zarówno jednostki, jak i społeczności. „Najlepsze efekty [takie porównania] przynosiłyby jednak wtedy, kiedy odbywałyby się dzięki stałej, opłacanej instytucji, której zadanie stanowiłoby [prowadzenie] rocznych obserwacji, ich zapisywanie oraz zestawianie"20.

Leibniz dość niejasno pisze, $\mathrm{w}$ jaki sposób miałaby być opłacana ta instytucja, w szczególności jeśli chodzi o lekarzy. Podkreśla, że „koniecznie nale-

\footnotetext{
${ }^{17}$ Ibidem, 148.

${ }^{18}$ Leibniz, O sposobie udoskonalenia medycyny, 141.

${ }^{19}$ Ibidem, 144.

${ }^{20}$ Leibniz, Podsumowanie dotyczace obserwacjimedycznych, które należy nieustannie podejmować $i$ kontynuować, 146.
} 
żałoby przyjąć i korzystać [z usług] dużo większej niż obecnie liczby dobrych medyków, tak jak konieczne by było, aby władza wypłacała im stałą pensję"21, przy czym wysokość pensji uzależniona byłaby od doświadczenia lekarza, ale także od jakości pracy, czyli od skuteczności leczenia. Zarazem jednak postuluje, aby lekarz otrzymywał „gwarantowane wynagrodzenie od pacjentów albo - wedle sposobności - ze środków publicznych, ilekroć przeprowadzi dobrą kurację"22, co miałoby zachęcać medyków do większej dbałości o pacjentów. Można by uznać, że intencją Leibniza było stworzenie motywacyjnego systemu wynagrodzeń finansowanego w części przez państwo, w części zaś przez pacjentów. Jednak wcześniej postulował, aby jedynie państwo finansowało działania medyczne:

Należy nakazać lekarzom brać [pieniądze] nie od pacjentów, a tylko od państwa. Tak samo należy zakazać medykom przyjmowania jakichkolwiek podarków, w ten bowiem sposób utnie się wszelkie rozważania [na temat tego, komu pomagać,] i każdy człowiek będzie doglądany z tą samą pilnością. Z tego powodu [medycy] muszą składać przysięgi. [Medycy] muszą być utrzymywani przez państwo, zresztą tak jak ich rodziny. Najlepiej byłoby wtedy, gdyby została wśród nich przyjęta reguła [...] zakonu. Ponieważ zakonnicy są bezinteresowni. Stworzony przez nich zakon byłby najlepszym środkiem do rozwijania chrześcijaństwa, czego trzeba sobie życzyćc $c^{23}$.

Stanowisko Leibniza nie jest więc jednoznaczne i możemy jedynie domniemywać, że z jednej strony przyświecał mu ideał pracy lekarzy jako bezinteresownej służby dla dobra ludzi chorych, $\mathrm{z}$ drugiej strony jednak realistycznie oceniał biorące się ze słabości ludzkiej natury lekarzy ich pragnienie osiągania korzyści materialnych i widział konieczność pójścia na jakieś ustępstwa w tej kwestii.

Leibniz uznał, że właściwa organizacja - mówiąc dzisiejszym językiem służby zdrowia pozwoli na ograniczenie interesu własnego lekarzy i wzbudzenie w nich postawy służebnej. Najbardziej stosowną formą organizacyjną wydał mu się zakon. Pisze wprost: „Trzeba urządzić medycynę na wzór Kościoła"24. Jeśli chodzi o strukturę organizacyjną, to Leibniz zdaje się przejmować wzorzec podziału parafialnego: „Każda główna ulica albo kwartał

\footnotetext{
${ }^{21}$ Leibniz, Propozycja utworzenia urzędu zdrowia, 134.

${ }^{22}$ Ibidem.

${ }^{23}$ Leibniz, Zalecenia dotyczące medycyny, 160.

${ }^{24}$ Ibidem.
} 
ludnego miasta powinny mieć zarówno własnego medyka, jak i pastora. Przy czym powinni działać także superintendenci tudzież superintendenci generalni”25. Jednak zdecydowanie ważniejsza od podziału organizacyjnego jest dlań kwestia akceptacji przez każdą jednostkę i przez całą społeczność tego wszystkiego, co dzięki tej organizacji ma być realizowane. Akceptacja ta ma być analogiczna do akceptacji działalności parafii - i tak jak parafia dba o zdrowie duchowe parafian, tak jednostka organizacyjna służby zdrowia ma dbać o zdrowie ich ciała. A ponieważ najważniejsze informacje o stanie zdrowia duchowego jednostki uzyskiwane są dzięki spowiedzi, więc metodę tę należy zastosować także w przestrzeni troski o zdrowie cielesne.

Wymagana będzie także spowiedź, do której ludzie będą wszakże chętnie przystępować. Jednakże po to, aby spowiedź przebiegała sprawniej, trzeba będzie powszechnie przedłożyć ludziom [odpowiednie] pytania - zupełnie tak, jak gdyby posiadało się książeczkę do spowiedzi, która mówi o tysiącu dających się pomyśleć grzechach, by nie zapomnieć o żadnym. Trzeba określić dokładne terminy w ciągu roku, w których każdy człowiek będzie mógł odbyć spowiedź medyczną i powiedzieć wszystko [swemu lekarzowi], przy czym pierwej powinno się ustalić czas, jaki zostawi się choremu na zastanowienie i przemyślenia. Dodatkowo każdy powinien mieć możliwość przystąpienia do spowiedzi nadzwyczajnej. I tak, jak w Kościele pozwala się na wybór swego spowiednika, który nie jest z probostwa, tak też musi być i tutaj, że ma się wędrownego (łac. vagos) medyka, który nie jest przywiązany do żadnej parafii, i dlatego będzie można wybrać tego, którego się zechce. I w sytuacjach wyjątkowych spowiednik prywatny będzie komunikował się z ordynaryjnym [tj. ze swym zwierzchnikiem]. Przy spowiedniku ordynaryjnym w spowiedzi generalnej powinno się powtórzyć wszystko to, co wyznało się wcześniej w prywatnej ${ }^{26}$.

Ta analogia do spowiedzi z popełnionych złych uczynków jest pełna. Po pierwsze, Leibniz nakłada na spowiednika medycznego obowiązek zachowania $\mathrm{w}$ tajemnicy przekazanych mu informacji i wprawdzie postuluje, by spowiednicy duchowi i medyczni komunikowali się ze sobą w celu wymiany użytecznych informacji dla dobra spowiadających się, jednak stawia bezwzględny wymóg ich anonimowości ${ }^{27}$. Po drugie zaś, tak jak spowied-

\footnotetext{
${ }^{25}$ Ibidem.

${ }^{26}$ Ibidem, 161.

${ }^{27}$ Ibidem, 162. Leibniz zakłada przy tym, że to dla spowiednika duchowego bardziej użyteczne będą informacje uzyskane od spowiednika medycznego, gdyż dzięki nim będzie mógł lepiej rozumieć stan psychiczny penitenta i w rezultacie skuteczniej nim kierować. Dlatego
} 
nik duchowy nie powinien poprzestawać na wyznaczeniu jednorazowego zadośćuczynienia, lecz nadto dawać stosowne wskazówki co do przyszłego postępowania penitenta, tak też spowiednik medyczny powinien wyznaczać właściwe dla danej jednostki reguły postępowania. „Tym, czym w spowiedzi duchowej jest nałożenie pokuty, tym tutaj powinno być przedłożenie zasad, według których należy postępować"28.

Podobnie jak wcześniej Jan Amos Komeński, ale niezależnie od niego, uznaje Leibniz troskę o zdrowie za równie ważną, jak troska o duszę. Jednak troska ta nie sprowadza się do wyznawanej przez starożytnych Greków zasady, że człowiek dzielny rozwija równomiernie swoją duszę i swoje ciało, aby jedno i drugie było piękne. I u Komeńskiego, i u Leibniza grecka areté (rzymska virtus) staje się cnotą w sensie chrześcijańskim, a więc trwałą zdolnością do czynienia dobra moralnego określonego prawem Boskim. Podstawą propozycji Leibniza jest przekonanie, że troska o ciało jest powinnością moralną człowieka w tym samym stopniu, jak troska o duszę. W liście do jezuity o. Joachima Bouveta z 1697 roku Leibniz podkreśla, że medycyna jest najbardziej potrzebną z nauk przyrodniczych, i wyjaśnia to poprzez znamienną analogię:

Tak jak teologia jest najwyższą wiedzą dotyczącą rzeczy duchowych, zawierając w sobie zarówno prawa moralne, jak i zasady właściwego postępowania, tak też można powiedzieć, iż medycyna również jest najwyższą wiedzą, będąc głównym owocem naszej znajomości ciał w takiej mierze, w jakiej mówią coś one o naszym własnym ciele. Wszelako wszystkie nauki przyrodnicze oraz sama medycyna mają jako swój cel ostateczny chwałę Boga i najwyższą szczęśliwość ludzi, ponieważ dbając o ich dobry stan, medycyna dostarcza im środków do działania na chwałę Bożą 29 .

Zdrowie nie jest zatem celem samym w sobie, lecz środkiem do celu samego w sobie, jakim jest służba Bogu z nadzieją osiągnięcia zbawienia. Celem troski o zdrowie jest więc bezpośrednio zachowanie jak najdłuższego życia w dobrym zdrowiu, ale pośrednim i ostatecznym celem jest życie wieczne.

Zachowania prozdrowotne stają się więc $\mathrm{w}$ istocie zachowaniami cnotliwymi, dbałość o zdrowie staje się cnotą, a tym samym zaniedbywanie zdrowia czy działania dla zdrowia szkodliwe stają się grzechem. Dostrzega też

postuluje, aby spowiednicy duchowi posiadali wiedzę na temat wpływu stanu fizjologicznego na stan psychiczny.

${ }^{28}$ Ibidem, 161. Szczególną wagę przywiązuje Leibniz do właściwej diety.

${ }^{29}$ Cyt. za: The Continuum Companion to Leibniz, red. Brandon C. Look, 261. 
Leibniz analogię $\mathrm{w}$ tym, że ludzie z lekkomyślności lub dla źle pojętej doraźnej korzyści równie łatwo rezygnują z zachowań prozdrowotnych, jak z zachowań cnotliwych.

Uważam za karę bożą, że byliśmy dotąd tak ślepi i nie kierowaliśmy choćby tysięcznej części naszej troski na takie rzeczy podstawowe, i nadal jej nie kierujemy. Mogę w pełni powiedzieć, że martwię się nieomal tak samo - przez analogię - gnuśnościa zdrowotną i duchową ${ }^{30}$.

Jak mocno stanowisko Leibniza osadzone jest w kontekście teologii moralnej, świadczy posłużenie się analogią między karą za grzechy a karą za brak troski o zdrowie: tak jak potępieniec $\mathrm{w}$ piekle doświadcza cierpienia, tak w życiu ziemskim człowiek zaniedbujący zdrowie doświadcza cierpień fizycznych. Dlatego tak ważne są wszelkie rady, pouczenia i zachęty uświadamiające ludziom konieczność stałej dbałości o zdrowie, a nie tylko wtedy, gdy zaczyna się choroba. Mówiąc językiem współczesnym: dlatego tak ważna jest edukacja prozdrowotna.

W cytowanej na początku niniejszych rozważań definicji zdrowia publicznego sformułowanej przez Światową Organizację Zdrowia można wyróżnić trzy zasadnicze aspekty, w jakich mają być realizowane działania służące ochronie zdrowia: (1) aspekt badawczy i analityczno-kontrolny, (2) aspekt organizacyjno-prawny, (3) aspekt edukacyjno-wychowawczy. W szystkie one zostały uwzględnione przez Leibniza. Zauważmy, że te trzy aspekty są ze sobą powiązane: praca badawcza, gromadzenie danych, ich analiza i wyciąganie wniosków nie są możliwe bez odpowiedniej organizacji i podstaw prawnych w skali co najmniej danego państwa, z kolei aby działania takie były jak najszersze i jak najskuteczniejsze, konieczne jest właściwe nastawienie całej społeczności, do czego może doprowadzić odpowiednia edukacja prozdrowotna. Współczesny rozwój zdrowia publicznego dokonuje się na takiej - wytyczonej przez Leibniza - drodze.

${ }^{30}$ Leibniz, Zalecenia dotyczace medycyny, 162. 
W świetle dynamicznego rozwoju nauk biomedycznych zalecenia Leibniza dotyczące gromadzenia wszelkich informacji mających znaczenie dla ochrony zdrowia mogą wydawać się jedynie historyczną ciekawostką, niemniej jednak to, co stanowi ich istotę, jest obecnie warunkiem koniecznym i wyznacznikiem wszelkich działań $\mathrm{w}$ zakresie zdrowia publicznego. Zarówno działalność bieżąca, jak i tworzenie planów perspektywicznych nie byłyby możliwe bez istnienia rozbudowanych systemów gromadzenia, przetwarzania i wymiany informacji medycznych. Dzięki komputeryzacji potrafimy obecnie tworzyć różnorodne programy informatyczne będące bardzo skutecznymi narzędziami planowania i zarządzania w obszarze zdrowia publicznego $^{31}$. Z drugiej strony zaś dzięki Internetowi społeczeństwo posiada szeroki dostęp do wiedzy medycznej i możliwości dzielenia się tą wiedzą̧ ${ }^{32}$ Te ogromne możliwości byłyby zapewne niewyobrażalne dla ludzi minionych epok, nawet tak genialnych, jak Leibniz. Jednak jego intuicja była słuszna gromadzenie i przetwarzanie informacji medycznej jest warunkiem koniecznym skutecznych działań mających na celu polepszanie stanu zdrowotnego populacji. Współczesne zdrowie publiczne jako dziedzina wiedzy medycznej rozwija się dzięki coraz lepszemu i coraz szerszemu wdrażaniu tej intuicji.

Proces gromadzenia i przetwarzania informacji medycznych, zapoczątkowany już w czasach Leibniza, nabrał szczególnej dynamiki w połowie XX wieku. W obszarze medycyny społecznej i w odniesieniu do zdrowia całych populacji musiało to doprowadzić do zasadniczej zmiany polityki zdrowotnej. Z jednej strony dokonywał się proces poszerzania i pogłębiania wiedzy medycznej, co owocowało zwiększaniem skuteczności zapobiegania i leczenia, z drugiej strony zaś obejmowano opieką medyczną coraz szersze kręgi społeczne. Oba te czynniki musiały powodować ogromny wzrost kosztów zapobiegania, leczenia i rehabilitacji. Spełnianie nadziei Leibniza na rozwój wiedzy medycznej i realizowanie jego postulatu objęcia opieką medyczną całej populacji nieuchronnie prowadziło do sytuacji, której filozof zapewne nie przewidywał - że mianowicie państwowe i prywatne możliwości finansowe okażą się za małe, aby każdemu zapewnić taką ochronę zdrowia, na

\footnotetext{
${ }^{31}$ W czasopiśmie Medical Care 33, 12, Supplement (1995) można znaleźć opisy różnych systemów informatycznych tworzonych na potrzeby szeroko pojętej służby zdrowia. Zob. w szczególności Charlyn D. Black, Charles A. Burchill, Leslie L. Roos, „The Population Health Information System: Data Analysis and Software", ibidem, DS127-DS131.

${ }^{32}$ Zob. np. Todd H. Wagner et al., "Free Internet Access, the Digital Divide, and Health Information", Medical Care 43, 4 (2005). Odrębną kwestią jest jednak problem, jak odróżnićw tej masie danych informacje wartościowe od bezwartościowych, a nawet szkodliwych.
} 
jaką pozwala aktualny stan wiedzy. Tym samym jednak niejako równolegle do rozwoju wiedzy medycznej zaczął się proces badania przyczyn tej zależności i poszukiwania środków zaradczych.

Momentem przełomowym było opublikowanie w 1974 roku raportu New Perspectives on the Health of Canadians autorstwa Marca Lalonde'a, ówczesnego ministra zdrowia Kanady ${ }^{33}$. W raporcie została przedstawiona Koncepcja Obszarów Zdrowia (Health Field Concept), czyli grup czynników mających wpływ na stan zdrowia populacji. Lalonde wyróżnił cztery takie obszary: ludzkiej biologii (łącznie z uwarunkowaniami genetycznymi), środowiska (wszelkie czynniki społeczne, kulturowe, ekonomiczne i fizyczne), stylu życia (dieta i aktywność fizyczna) i organizacji opieki zdrowotnej. Celem było przejście od dotychczasowej, niewydolnej już polityki zdrowotnej, opartej na zwiększaniu świadczeń i poszerzaniu infrastruktury medycyny naprawczej, do polityki nowej, polegającej przede wszystkim na takim kształtowaniu środowiska naturalnego i ludzkich postaw, które najbardziej sprzyja zachowaniom ograniczającym w przyszłości konieczność bezpośredniej interwencji medycznej. Lalonde uznał, że główną przyczyną niskiej efektywności dotychczasowych metod opieki zdrowotnej jest rozpraszanie środków kierowanych na poszczególne, izolowane obszary działań prozdrowotnych. „Taka fragmentaryzacja odpowiedzialności prowadzi czasami do zachwiania równowagi między poszczególnymi przedsięwzięciami, gdy każdy uczestnik działań w obszarze służby zdrowia wprowadza określone rozwiązania tylko na własnym polu zainteresowań. Na gruncie Koncepcji Obszarów Zdrowia te fragmenty zostają połączone w jednolitą całość, co umożliwia każdemu dostrzeżenie ważności wszystkich czynników, także tych, za które odpowiedzialni są inni”34. Jak ujął to Trevor Hancock, koncepcja Lalonde’a umożliwiła przejście od polityki w zakresie zdrowia publicznego do zdrowej polityki $\mathrm{w}$ ramach zdrowia publicznego ${ }^{35}$.

\footnotetext{
${ }^{33}$ Marc Lalonde, New Perspectives on the Health of Canadian A Working Dokument, Ottawa 1974. Dostęp 12.01.2016. http://www.phac-aspc.gc.ca/ph-sp/pdf/perspect-eng.pdf.

${ }^{34}$ „This fragmentation of responsibility has sometimes led to imbalanced approaches, with each participant in the health field pursuing solutions only within his area of interest. Under the Health Field Concept, the fragments are brought together into a unified whole which permits everyone to see the importance of all factors, including those which are the responsibility of others"; ibidem, 33.

35 Trevor Hancock, „Beyond Health Care: From Public Health Policy to Healthy Public Policy", Canadian Journal of Public Health 76, 1, Supplement (1985).
} 
Dalszy rozwój zdrowia publicznego zmierzał drogą wytyczoną przez Lalonde’a i był wspierany kolejnymi inicjatywami podejmowanymi na szczeblu międzynarodowym pod auspicjami Światowej Organizacji Zdrowia ${ }^{36}$. Znaczącym wydarzeniem była odbyta we wrześniu 2012 roku coroczna sesja Regionalnego Komitetu WHO ds. Europy, na której państwa członkowskie Europejskiego Regionu WHO przyjęły ramy polityki Zdrowie 2020. Celem przyjętych decyzji i zobowiązań ma być doprowadzenie w Europie do zwiększenia przeciętnej długości życia, zmniejszenia istniejących nierówności $\mathrm{w}$ dostępie do opieki zdrowotnej i zapewnienia jej powszechności ${ }^{37}$. Sygnatariusze dokumentu wyrazili przekonanie, że „można realizować efektywną kosztowo politykę, która przyczynia się do bezpośredniej poprawy poziomu zdrowia i dobrostanu ludności, wykorzystując przywództwo rządu i wspierające środowiska oraz promując wśród społeczeństwa poczucie posiadania kontroli i upodmiotowienia" ${ }^{38}$.

Polityka prozdrowotna ma więc charakter holistyczny i to w dwu wymiarach: jako obejmująca całość ludzkich zachowań wpływających na poziom zdrowotności zarówno jednostek, jak społeczności oraz jako realizująca działania prozdrowotne w skali całego kraju, a nawet w miarę możliwości w skali międzynarodowej. Można postawić tezę, że gdyby propozycje Leibniza były sukcesywnie wprowadzane w życie, to musiałyby prowadzić do takich samych lub zbliżonych rozwiązań dotyczących badań, analizy, kontroli, organizacji i regulacji prawnych w zakresie zdrowia publicznego. Można powiedzieć nawet, że faktycznie zaczęto jego propozycje realizować, choć nie powoływano się na niego. Droga, którą kroczy rozwój zdrowia publicznego, jest konieczną konsekwencją przyjęcia jako oczywistych dwu tez: pierwszej, że zdrowie jednostki i całej populacji zależy od warunków, w jakich jednostka żyje, a także od jakości i stylu jej życia, oraz drugiej, iż w konsekwencji zdrowie nie jest tylko problemem jednostki, lecz także problemem państwa. Obie tezy są wyraźnie obecne w propozycjach Leibniza.

Prekursorstwo Leibniza nie byłoby jednak pełne, gdyby nie ten aspekt jego propozycji, bez którego nie jest możliwa współczesna polityka prozdrowotna, mianowicie aspekt edukacyjny. Podstawowym zadaniem zdrowia publicznego jest promocja zdrowia oparta na przekonaniu, że jednostka musi

\footnotetext{
${ }^{36}$ Mirosław J. Wysocki, Maria Miller, „Paradygmat Lalonde’a, Światowa Organizacja Zdrowia i Nowe Zdrowie Publiczne", Przegląd Epidemiologiczny 57, 3 (2003).

${ }^{37}$ Zsuzsanna Jakab, Agis D. Tsouros, „Zdrowie 2020 - zdrowie i rozwój współczesnej Europy”, Przegląd Epidemiologiczny 69, 1 (2015), 105-112.

${ }^{38}$ Ibidem, 105.
} 
być poddawana wychowywaniu prozdrowotnemu, dzięki któremu staje się ona coraz pełniej świadoma zależności przyczynowo-skutkowych między jej działaniami a stanem jej zdrowia. Celem tego wychowania jest kształtowanie w jednostkach, a w konsekwencji także w społeczności, racjonalnego stosunku do zdrowia i choroby oraz poczucia odpowiedzialności za zdrowie własne i współodpowiedzialności za zdrowie społeczeństwa ${ }^{39}$. Postulat Leibniza wprowadzenia swoistej „spowiedzi medycznej” może wydawać się nieprzystający do obecnych czasów, jednak wrażenie takie jest mylne, gdyż opiera się jedynie na zewnętrznej formie tej propozycji. To jednak, co stanowi jej istotę, jest w pełni realizowane w obecnych czasach. Twierdzenie Leibniza, że tak jak każdy człowiek powinien coś robić i czegoś nie robić ze względu na zbawienie duszy, tak też powinien czynić pewne rzeczy i nie czynić innych ze względu na zdrowie ciała, w istocie wyraża przekonanie, że dbałość o zdrowie jest powinnością moralną. Przekonanie to nie musi funkcjonować w kontekście religijnym i może być rozumiane bez jakichkolwiek odniesień do religijnie rozumianego prawa naturalnego. I tak jest ono faktycznie rozumiane $\mathrm{w}$ ramach zdrowia publicznego - uznaje się, że z perspektywy celów prozdrowotnych pewne działania są niewskazane, inne zaś wskazane, analogicznie jak ze względu na konieczność zachowania ładu społecznego pewne działania są zakazywane, inne zaś nakazywane przez kodeksy karne.

Analogia z kodeksem karnym nie idzie bynajmniej za daleko. We współczesnym świecie, w krajach wysoko rozwiniętych, zarówno jednostki, jak i całe społeczeństwa poddawane są silnej presji ze strony instytucji zdrowia publicznego, presji sankcjonowanej przepisami prawa ${ }^{40}$. Edukacja prozdrowotna przybiera formy perswazyjnej propagandy o charakterze quasi-religijnym, odwołującej się do poczucia odpowiedzialności za siebie i innych, przede wszystkim zaś nasila się ingerencja w życie społeczne polegająca na zmuszaniu jednostek do zachowań uznanych za wskazane i zabranianiu zachowań uznanych za szkodliwe. Dawniej nauczanie religijne miało za cel kształtowanie określonych postaw i zachowań w trosce o duszę, współcześnie zaś zadaniem wychowania prozdrowotnego jest kreowanie różnego rodzaju zachowań (określanych jako „zdrowe”: zdrowy tryb życia, odżywiania się, ubieranie itp.) w trosce o zdrowie. Momentem przełomowym w tym zakresie było przyjęcie przez wspólnotę międzynarodową tzw. Karty Ottawskiej,

\footnotetext{
${ }^{39}$ Promocja zdrowia, red. Jerzy B. Karski (Warszawa: Wydawnictwo Ignis, 1999).

${ }^{40}$ Robert M. Veatch, „Voluntary Risks to Health. The Ethical Issues”, Journal of American Medical Association 243, 1 (1980).
} 
dokumentu uchwalonego w trakcie konferencji poświęconej promocji zdrowia, odbytej w stolicy Kanady 17-21 listopada 1986 roku $^{41}$. Karta Ottawska wyznaczyła jako idealny cel osiągnięcie pełnego dobrostanu zdrowotnego, wskazała też środki polityczne, ekonomiczne, prawne i społeczne, za pomocą których należy do tego celu zmierzać. $\mathrm{W}$ istocie zdrowie zostało uznane za dobro najwyższe, a troska o zdrowie za powinność moralną jednostek i obowiązek społeczny władzy państwowej ${ }^{42}$. Często wskazuje się, że zmierzamy do stworzenia społeczeństwa zmedykalizowanego, czyli takiego, w którym jednostka zmuszana jest środkami perswazyjnymi i prawnymi do zachowań uznanych za prozdrowotne ${ }^{43}$. Jeśli pominiemy te osobliwości propozycji Leibniza, które są jedynie odzwierciedleniem ducha czasów jemu współczesnych, to musimy uznać, że wytyczają one drogę rozwojową współczesnej nam edukacji prozdrowotnej.

Można zatem uznać Leibniza za prekursora zdrowia publicznego i to we wszystkich jego trzech aspektach: badawczym, organizacyjno-prawnym i wychowawczym. Leibniz zmierzał wyraźnie do stworzenia projektu całościowego systemu opieki zdrowotnej sprawowanej zarówno nad jednostką, jak i nad społecznością, w której jednostka żyje; wprawdzie jego propozycje nie złożyły się na skończony model zdrowia publicznego, jednak niewątpliwie takie były jego intencje. Wprawdzie pozostawił jedynie fragmentaryczne sugestie i zalecenia, ale czynione były one przy założeniu, że opieka zdrowotna ma nie tylko jednostkowy, lecz także społeczny wymiar, a jej realizacja wymaga koordynacji działań w skali społeczności i całego państwa. Gdyby więc jego propozycje były konsekwentnie rozwijane, prowadziłyby do kształtowania holistycznego modelu zdrowia publicznego - i takie właśnie działania zaczęto podejmować w XIX wieku, a zostały one zdynamizowane w czasach współczesnych. Niewątpliwie waga, jaką Leibniz przywiązywał do społecznego wymiaru medycyny, była swoistą wypadkową naturalnej dla człowieka

\footnotetext{
${ }^{41}$ Tekst angielski Karty: http://www.who.int/healthpromotion/conferences/previous/ottawa/ en/. Przekład polski: www.fais.home.pl/www/images/docs/ottawa. Wszystkie późniejsze ustalenia w zakresie promocji zdrowia nawiązują do zapisów Karty Ottawskiej.

${ }^{42}$ Maria Nowacka, „Promocja zdrowia jako czynnik medykalizacji społecznej. Uwagi w odniesieniu do Karty Ottawskiej", w: Etyka w medycynie - Wczoraj i dziś. Wybrane zagadnienia, red. Krystyna Basińska, Jacek Halasz, (Kraków: Oficyna Wydawnicza Impuls, 2013), 133-147.

${ }^{43}$ Lesław Niebrój, „Promocja zdrowia: nowy totalitaryzm?”, Annales Academiae Medicae Silesiensis, suplement 34 (2002). Zob. także Zbigniew Zalewski, „Co kryje się za promocją zdrowia?", Sztuka leczenia III, 1 (1997).
} 
troski o własne zdrowie ${ }^{44}$ i genialnej intuicji naukowej. Zarazem jednak jego propozycje wpisują się w kontekst podejmowanej przezeń tematyki z zakresu filozofii polityki i są zgodne z żywionym przezeń arystotelesowskim przekonaniem, że właściwym celem działań politycznych jest dobro wspólne danej społeczności. W liście do Pierre’a Falaiseau z 8 lipca 1705 roku pisał: „Każdy rozsądny człowiek musi przyznać, iż rząd jest po to, aby dbać o dobro wspólne. Wedle mojej definicji państwa, czyli tego, co po łacinie zwie się respublica, jest ono dużą społecznością, która ma za cel zapewnienie publicznego dobrostanu" ${ }^{45}$. Mówiąc o publicznym dobrostanie, Leibniz używa łacińskiego zwrotu securitas publica, przy czym rozumie go w szerokim sensie jako oznaczający nie tylko bezpieczeństwo fizyczne, lecz mieszczący w swym zakresie także wszelkie formy ochrony socjalnej ${ }^{46}$. Do tak rozumianej securitas publica zaliczał także troskę o zdrowie. Współczesne rozumienie zdrowia publicznego mieści się całkowicie w tej kategorii.

\section{Bibliografia}

Basso Luca. 2011 “The Republic in Leibniz: Between Philosophy and Politics”, Studia Leibnitiana 43 (1): 103-121.

Black Charlyn D., Charles A. Burchill, Leslie L. Roos. 1995. The Population Health Information System: Data Analysis and Software, „Medical Care” 33, 12, Supplement: DS127-DS131.

Chazaud Jacques. 1995. „G. W. Leibniz. Médecine et sciences de la vie”, Histoire des Sciences Médicales XXIX (3): 237-242.

Hancock Trevor. 1985. „Beyond Health Care: From Public Health Policy to Healthy Public Policy”, Canadian Journal of Public Health (76) 1, Supplement: 9-11. Jakab Zsuzsanna. 2015. „Zdrowie 2020 - zdrowie i rozwój współczesnej Europy”, Przegląd Epidemiologiczny (69) 1: 105-112.

\footnotetext{
${ }^{44}$ Leibniz, jak zaświadcza jego sekretarz, cieszył się raczej dobrym zdrowiem, dopisywał mu apetyt, nie nadużywał trunków i prowadził uregulowany tryb życia;zob. The Cambridge Companion to Leibniz, red. Nicholas Jolley, Cambridge: Cambridge University Press, 1995, 38.

${ }^{45}$ Cyt. za: Luca Basso, „The Republic in Leibniz: Between Philosophy and Politics”, Studia Leibnitiana 43, 1 (2011), 115.

${ }^{46}$ Luca Basso tak to wyjaśnia: „Securitas publica denotes not only an apparatus of security in the strict sense, but also a complex series of forms of social protection for the individuals within the articulated spheres in which they are set"; ibidem.
} 
Jolley Nicholas, red. 1995. The Cambridge Companion to Leibniz, Cambridge: Cambridge University Press.

Karski Jerzy B. red., 1999. Promocja zdrowia, Warszawa: Wydawnictwo Ignis.

Lalonde Marc. 1974. New Perspectives on the Health of Canadians. A Working Dokument, Ottawa, dostęp 12.05.2016; http://www.phac-aspc.gc.ca/ph-sp/pdf/perspect-eng.pdf.

Leibniz Gottfried Wilhelm. 2013. „Zalecenia dotyczące medycyny”, tłum. K. Pękacka-Falkowska, Klio. Czasopismo poświęcone dziejom Polski i powszechnym (24) 1: $144-168$.

Leibniz Gottfried Wilhelm. 2010. „Propozycja utworzenia urzędu zdrowia”, tłum. K. Pękacka-Falkowska, Klio. Czasopismo poświęcone dziejom Polski i powszechnym (15): 133-139.

Leibniz Gottfried Wilhelm. 2010. „O sposobie udoskonalenia medycyny”, tłum. T. Falkowski, Klio. Czasopismo poświęcone dziejom Polski i powszechnym (15): 141-144.

Leibniz Gottfried Wilhelm. 2010. „Podsumowanie dotyczące obserwacji medycznych, które należy nieustannie podejmować i kontynuować”, tłum. K. Pękacka-Falkowska, Klio. Czasopismo poświęcone dziejom Polski i powszechnym (15): 145-150.

Niebrój Lesław. 2002. „Promocja zdrowia: nowy totalitaryzm?”, Annales Academiae Medicae Silesiensis, Suplement (34): 71-77.

Nowacka Maria. 2013. „Promocja zdrowia jako czynnik medykalizacji społecznej. Uwagi w odniesieniu do Karty Ottawskiej" W: Etyka w medycynie - Wczoraj i dziś. Wybrane zagadnienia, red. Krystyna Basińska, Jacek Halasz, Kraków: Oficyna Wydawnicza Impuls, 133-147.

Nowacka Maria. 2014. „Rozwój medycyny a poziom świadomości zdrowotnej w XVII wieku”, Roczniki Filozoficzne LXII (4): 103-120.

Nowacka Maria. 2015. „Jan Amos Komeński o powinnościach prozdrowotnych”, Idea. Studia nad struktura i rozwojem pojęć filozoficznych XXVII/t.t.

Pękacka-Falkowska Katarzyna. 2010. Leibniz i instytucjonalizacja opieki medycznej albo o trzech tekstach z 1690, 1694 i 1701 roku, Klio. Czasopismo poświęcone dziejom Polski i powszechnym (15): 125-131.

Pękacka-Falkowska Katarzyna. 2013. „Gottfried Wilhelm Leibniz o sposobie udoskonalenia medycyny”,Klio. Czasopismo poświęcone dziejom Polski i powszechnym 24, (1): 139-143.

Pękacka-Falkowska Katarzyna. 2017. „Młody Leibniz i medycyna jego epoki. W stronę instytucjonalizacji sztuki leczenia".W: Filozofia medycyny - rozważania o tradycji i współczesności, red. Marcin Moskalewicz, Jan Zamojski, 49-63. Poznań: Wydawnictwo Naukowe Uniwersytetu Medycznego w Poznaniu. 
Smith Justin E. H. 2011. „Leibniz and the life sciences”. W: The continuum companion to Leibniz, red. Brandon C. Look. London-New York: Continuum International Publishing Group : 259-274.

Trunk Achim, „An early concept of G. W. Leibniz regarding medicine”.W: The global and the local: The history of science and the cultural integration of Europe, Proceedings of the $2^{\text {nd }}$ ICESHS (Cracow, Poland, September 6-9, 2006), red. Michał Kokowski, dostęp 12.05.2016, www.2iceshs.cyfronet.pl/2ICESHS_Proceedings/ Chapter_13/R-5_Trunk.pdf.

Veatch Robert M. 1980. Voluntary Risks to Health. The Ethical Issues, „Journal of American Medical Association" 243 (1): 50-55.

Wagner Todd H. 2005. Bundorf M. Kate, Singer, Sara J., Baker, Laurence C., „Free Internet Access, the Digital Divide, and Health Information", Medical Care 43, (4): 415-420.

Wysocki Mirosław J., Maria Miller. 2003. „Paradygmat Lalonde’a, Światowa Organizacja Zdrowia i Nowe Zdrowie Publiczne", Przegląd Epidemiologiczny 57 (3): 505-512.

Zalewski Zbigniew. 1997. Co kryje się za promocja zdrowia?, „Sztuka leczenia” III (1): 19-26.

\section{Abstract \\ Leibniz as a Precursor of Public Health}

This article argues that the proposals concerning the organization of medical activities put forward by Leibniz make it possible to consider him as a precursor of public health. His proposals can be analyzed with reference to three aspects: research, organizational-legal and didactic. Leibniz was clearly in favour of the creation of a holistic system of healthcare both regarding an individual and a social community which an individual belongs to. All his proposals were based on the assumption that the social dimension of healthcare was as important as the individual one, which is why he believed that healthcare activities should be coordinated at the level of the society and the entire state. Consistency in putting his proposals into practice can be expected to lead to the creation of a holistic model of public health - such activities began in the $19^{\text {th }}$ century and continue - with increasing intensity - until the present. Leibniz's proposals concerning healthcare are also connected with the issues in the philosophy of politics which he took up in his research and follow the Aristotelian belief which he shared that the common good of a given community is the ultimate aim of political activities.

Keywords: Leibniz, healthcare, public health 


\section{Streszczenie}

\section{Leibniz jako prekursor zdrowia publicznego}

W artykule uzasadnia się, że propozycje Leibniza dotyczące organizacji działań medycznych pozwalają uznać go za prekursora zdrowia publicznego $\mathrm{w}$ trzech podstawowych aspektach: badawczym, organizacyjno-prawnym i wychowawczym. Leibniz zmierzał wyraźnie do stworzenia projektu całościowego systemu opieki zdrowotnej sprawowanej zarówno nad jednostką, jak i nad społecznością, w której jednostka żyje; wszystkie jego propozycje były czynione przy założeniu, że opieka zdrowotna ma nie tylko jednostkowy, lecz także społeczny wymiar, a jej realizacja wymaga koordynacji działań w skali społeczności i całego państwa. Gdyby te propozycje były konsekwentnie rozwijane, prowadziłyby do kształtowania holistycznego modelu zdrowia publicznego - i takie właśnie działania zaczęło podejmować od XIX wieku poczynając, a zostały one zdynamizowane w naszych czasach. Zarazem jego propozycje wpisują się w kontekst podejmowanej przezeń tematyki z zakresu filozofii polityki i są zgodne zżywionym przezeń arystotelesowskim przekonaniem, że właściwym celem działań politycznych jest dobro wspólne danej społeczności.

Słowa kluczowe: Leibniz, opieka zdrowotna, zdrowie publiczne 